\title{
Nongoitrous autoimmune thyroiditis with facial palsy
}

\author{
Hyung Jik Lee, MD, \\ Jin Kyung Kim, MD
}

Department of Pediatrics, Catholic University of Daegu School of Medicine, Daegu, Korea
Received: 7 April, 2013

Revised: 7 November, 2013

Accepted: 23 December, 2013

Address for correspondence:

Jin Kyung Kim, MD, PhD

Department of Pediatrics, Catholic

University of Daegu School of

Medicine, 33 Duryugongwon-ro

17-gil, Nam-gu, Daegu 705-718,

Korea

Tel: $+82-53-650-4240$

Fax: +82-53-621-4106

E-mail:kimjk@cu.ac.kr
We report a case of severe hypothyroidism with nongoitrous, autoimmune thyroiditis and pituitary hyperplasia in a 13-year-old boy, who presented with sudden palsy on the left side of his face. Prednisolone and antiviral medication was administered. However, the facial palsy did not improve completely. The medications were replaced with thyroxine, and the facial palsy recovered. Endocrinological testing showed severe hypothyroidism as follows: thyroid stimulating hormone (TSH) level $>100 \mu \mathrm{lU} / \mathrm{mL}, \mathrm{T}_{4}$ of $1.04 \mu \mathrm{g} / \mathrm{dL}, T_{3}$ of $0.31 \mathrm{ng} / \mathrm{mL}$, and free $T_{4}$ of $0.07 \mathrm{ng} / \mathrm{dL}$. Level of serum antithyroid peroxidase antibodies was $1,933.39 \mathrm{IU} / \mathrm{mL}$, and that of antithyroglobulin antibodies was $848.16 \mathrm{IU} / \mathrm{mL}$. Level of TSH receptor antibodies was $>40 \mathrm{IU} / \mathrm{L}$. Bioassay result for TSH receptor stimulating antibodies was negative. Thyroid sonography revealed no increase in the size or vascularity of the bilateral gland. Thyroid scintigraphy with 99mTc showed decreased uptake, and magnetic resonance imaging demonstrated an enlarged pituitary gland.

Keywords: Autoimmune thyroiditis, Facial palsy, Hypothyroidism

\section{Introduction}

Facial nerves have a long intracranial course and path through a narrow bony canal, thus, they are prone to injury due to middle ear or temporal bone infections, trauma, surgery or compression by a tumor. Bell palsy is the most common type of peripheral facial palsy in children, however, peripheral facial palsy could also signal the presence of a serious underlying disease ${ }^{1)}$.

Only a few reports have found facial palsy to be associated with hypothyroidism in adult patients ${ }^{2,3)}$, and none reported this association in children or adolescents.

We report a case of severe hypothyroidism with nongoitrous, autoimmune thyroiditis and pituitary hyperplasia in a 13-year-old boy, who presented with sudden palsy on the left side of his face. Prednisolone and antiviral medication was administered, however, the facial palsy did not improve as cases of Bell palsy typically do. The medications were replaced with thyroxine, and the facial palsy recovered completely.

To our knowledge, this is the first reported case of facial palsy associated with hypothyroidism in children or adolescents.

\section{Case report}

A 13-year-old boy presented with sudden palsy of the left side of the face. Prednisolone (60 $\mathrm{mg} /$ day) and acyclovir $(800 \mathrm{mg} /$ day $)$ were prescribed, however, the patient's facial palsy did not improve completely as we expected it was Bell palsy. He appeared lethargic and pale, and his parents suspected he had gained weight over the past two years. They also suspected his chronic fatigue was due to the weight gain.

The patient had no history of a viral infection, exposure to high levels of iodide or any medication. He was born at term weighing $3,500 \mathrm{~g}$ by spontaneous vaginal delivery without complication, and is the first child of unrelated parents. He also had no family history of any autoimmune or thyroid disease. His father's height was $176 \mathrm{~cm}$. Mother's height was $155 \mathrm{~cm}$, 
The mid parental height was $172 \mathrm{~cm}$. His blood pressure was $100 / 60 \mathrm{mmHg}$, and ha had pulse rate of 70 beats/min.

Upon physical examination, he was found to be myxedematous with coarse facial features including dry and thickened skin. However, no goiter was found. His weight, height, and body mass index (BMI) were $68.5 \mathrm{~kg}$ (90-95 percentile), $155 \mathrm{~cm}$ (50th percentile), and $28.5 \mathrm{~kg} / \mathrm{m}^{2}$ ( $>97$ th percentile), respectively. Pubertal development was also noted (penis, Tanner stage 2-3; pubic hair, Tanner stage 1; testis, 6-8 mL). Ophthalmological examinations, including a visual field test, revealed no abnormal findings.

Laboratory data revealed normocytic normochromic anemia (hemoglobin, $10.3 \mathrm{~g} / \mathrm{dL}$ ), and increased aspartate transaminase $(68 \mathrm{IU} / \mathrm{L})$, and alanine transaminase (139 $\mathrm{IU} / \mathrm{L}$ ), hypercholesteremia (total cholesterol, $378 \mathrm{mg} / \mathrm{dL}$ ), hypertriglycemia $(409 \mathrm{mg} / \mathrm{dL}$ ), and increased creatine kinase

Table 1. Serial laboratory data at first visit and after three months

\begin{tabular}{|c|c|c|c|}
\hline Variable & Atfirstvisit & After 3 monthslater & Normal range \\
\hline Hemoglobin (g/dL) & 10.3 & 11.9 & $12.9-16.9$ \\
\hline AST(IU/L) & 68 & 39 & $<35$ \\
\hline $\mathrm{ALT}(\mathbb{U} / \mathrm{L})$ & 139 & 56 & $<40$ \\
\hline$C K(I U / L)$ & 912.2 & 97.3 & $30-180$ \\
\hline Cholesterol (mg/dL) & 378 & 182 & $<200$ \\
\hline Triglyceride (mg/dL) & 409 & 118 & $<200$ \\
\hline $\mathrm{Na}(\mathrm{mEq} / \mathrm{L})$ & 136 & 141 & $135-148$ \\
\hline$K(m E q / L)$ & 4.0 & 4.7 & $3.5-5.5$ \\
\hline $\mathrm{Cl}(\mathrm{mEq} / \mathrm{L})$ & 97 & 105 & $98-110$ \\
\hline
\end{tabular}

AST, aspartate transaminase; ALT, alanine transaminase; CK, creatine kinase.

Table 2. Serial endocrinological data at first visit and after three months

\begin{tabular}{|c|c|c|c|}
\hline Variable & Atfirstvisit & $\begin{array}{c}\text { After } 3 \\
\text { months later }\end{array}$ & Normal range \\
\hline $\mathrm{TSH}(\mu \mathrm{lU} / \mathrm{mL})$ & $>100$ & 2.05 & $0.5-4.8$ \\
\hline $\mathrm{T}_{3}(\mathrm{ng} / \mathrm{mL})$ & 0.30 & 1.96 & $1.19-2.18$ \\
\hline FreeT $_{4}(\mathrm{ng} / \mathrm{dL})$ & 0.077 & 1.59 & $0.8-2.3$ \\
\hline Antithyroid peroxidase (IU/mL) & $1,933.39$ & & $<10$ \\
\hline Antithyroglobulin Ab (IU/mL) & 848.16 & & $<100$ \\
\hline TRAb (TBII,IU/L) & $>40$ & $>40$ & $0.3-1.22$ \\
\hline TSH receptor stimulating antibodies & Negative & & Negative \\
\hline Prolactin (ng/mL) & 29.04 & 7.45 & $3-18$ \\
\hline Cortisol ( $\mu \mathrm{g} / \mathrm{dL})$ & 6.69 & 4.36 & $3-21$ \\
\hline $\mathrm{ACTH}(\mathrm{pg} / \mathrm{mL})$ & 20.31 & 22.23 & $10-60$ \\
\hline$L H(m \| U / m L)$ & 1.32 & 3.49 & SMRII:0.2-4.9 \\
\hline \multicolumn{4}{|l|}{ SMRIII:0.2-5.0 } \\
\hline $\mathrm{FSH}(\mathrm{mlU} / \mathrm{mL})$ & 4.29 & 4.79 & SMRII:1.8-3.2 \\
\hline \multicolumn{4}{|l|}{ SMRIII:1.2-5.8 } \\
\hline Testosterone(ng/mL) & 0.20 & 1.82 & SMRII:0.18-1.5 \\
\hline \multicolumn{4}{|l|}{ SMRIII:2.0-6.2 } \\
\hline IGF-1 (ng/mL) & 105.0 & 350.0 & $145.2-647.8$ \\
\hline IGFBP-3 (ng/mL) & 3,270 & 5,230 & $2,200-4,490$ \\
\hline
\end{tabular}

$\overline{\mathrm{TSH}}$, thyroid stimulating hormone; $\mathrm{T}_{3}$, total triiodothyronine; Free $_{4}$, free thyroxine; Ab, antibody; TRAb, TSH receptor antibody; ACTH, adrenocorticotropic hormone; LH, lutenizing hormone; FSH, follicle stimulating hormone; IGF-1, insulin-like growth factor-1;/GFBP-3, insulin-like growth factorbinding protein-3.
(912.2 IU/L) levels (Table 1). Endocrinological testing showed severe primary hypothyroidism, elevated thyroid stimulating hormone level (TSH $>100 \mu \mathrm{IU} / \mathrm{mL}$ ) (normal range, 0.5 to 4.8 $\mu \mathrm{IU} / \mathrm{mL})$, decreased total thyroxine level $(1.04 \mu \mathrm{g} / \mathrm{dL})(4.5$ to $12.0 \mu \mathrm{g} / \mathrm{dL})$, decreased total triiodothyronine level $(0.31 \mathrm{ng} / \mathrm{mL})$ ( 1.19 to $2.18 \mathrm{ng} / \mathrm{mL})$ and decreased free thyroxine level $(0.07$ $\mathrm{ng} / \mathrm{dL})(0.8$ to $2.3 \mathrm{ng} / \mathrm{dL})$, In addition, elevated levels of serum antithyroid peroxidase antibodies $(1,933.39 \mathrm{IU} / \mathrm{mL})(<10 \mathrm{IU} /$ $\mathrm{mL})$, antithyroglobulin antibodes $(848.16 \mathrm{IU} / \mathrm{mL})(<100 \mathrm{IU} /$ $\mathrm{mL}$ ), and TSH receptor antibodies (immunoassay $>40 \mathrm{IU} / \mathrm{L}$ ) ( 0.3 to $1.22 \mathrm{IU} / \mathrm{L})$ were found. The results of the bioassay were negative for TSH receptor stimulating antibodies (Table 2).

Additional results of the laboratory analysis are as follows: prolactin, $29.04 \mathrm{ng} / \mathrm{mL}$ (3 to $18 \mathrm{ng} / \mathrm{mL}$ ); morning serum cortisol, $6.69 \mu \mathrm{g} / \mathrm{dL}$ (3 to $21 \mu \mathrm{g} / \mathrm{dL}$ ); adrenocorticotropic hormone, 20.31 $\mathrm{pg} / \mathrm{mL}$ (10 to $60 \mathrm{pg} / \mathrm{mL})$; growth hormone, $0.08 \mathrm{ng} / \mathrm{mL}(0.07$ to $5.68 \mathrm{ng} / \mathrm{mL}$ ); insulin like growth factor-I (IGF-I), $105.0 \mathrm{ng} /$ $\mathrm{mL}$ (145.2 to $647.8 \mathrm{ng} / \mathrm{mL}$ ); IGF binding protein-3 (IGFBP-3), $3,270 \mathrm{ng} / \mathrm{mL}$ (2,200 to $4,490 \mathrm{ng} / \mathrm{mL})$; luteinizing hormone, 1.32 $\mathrm{mIU} / \mathrm{mL}(0.2$ to $4.9 \mathrm{mIU} / \mathrm{mL})$; follicle stimulating hormone, 4.29 $\mathrm{mIU} / \mathrm{mL}$ (1.8 to $3.2 \mathrm{mIU} / \mathrm{mL})$; and testosterone, $0.2 \mathrm{ng} / \mathrm{mL}(0.18$ to $1.5 \mathrm{ng} / \mathrm{mL}$ ) (Table 2). According to the Greulich-Pyle method, bone age was 12.5 years (chronological age, 13 years). Thyroid sonography revealed a heterogenous internal structure; neither the size nor the vascularity of the bilateral gland was increased (Fig. 1). Thyroid scintigraphy with ${ }^{99 \mathrm{~m}} \mathrm{Tc}$ revealed a substantially decreased uptake in both lobes (Fig. 2). Magnetic resonance images displayed an enlarged pituitary gland, with upward convexity, measuring $13.0 \mathrm{~mm}$ in height and a transverse diameter of $8 \mathrm{~mm}$ (Fig. 3).

After L-thyroxin treatment was initiated, the symptoms of facial palsy and the patient's clinical condition improved (Tables 1,2). After 3 months, the second magnetic resonance images revealed a regression of the pituitary hyperplasia and a smaller pituitary gland than that from the first round of images. This condition was described as reactive hyperplasia caused by primary hypothyroidism. After 8 months, follow-up thyroid sonography revealed that the parenchymal echogenicity was coarse, and had decreased in size. However, changes to the size or echogenicity of the thyroid gland were not significant.

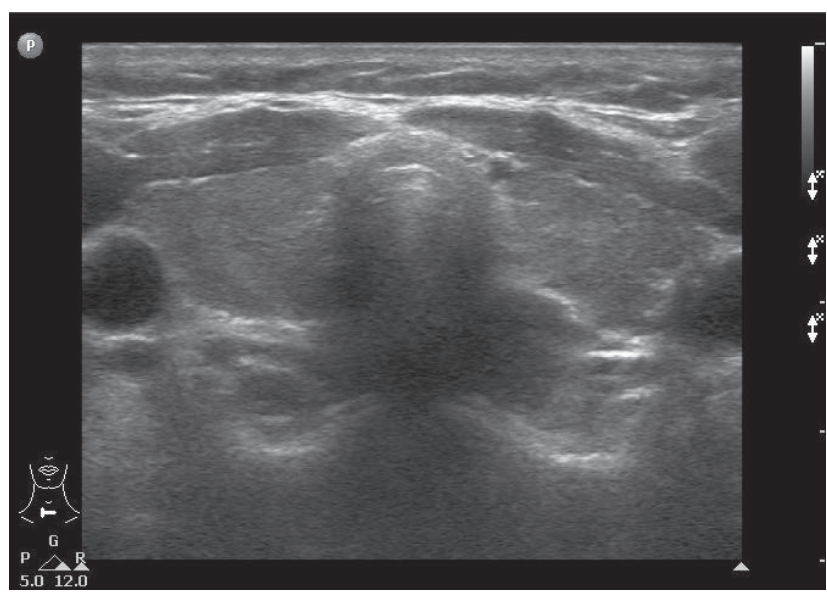

Fig. 1. Thyroid sonography shows a heterogenous internal structure without an increase in size or vascularity of the bilateral gland. 

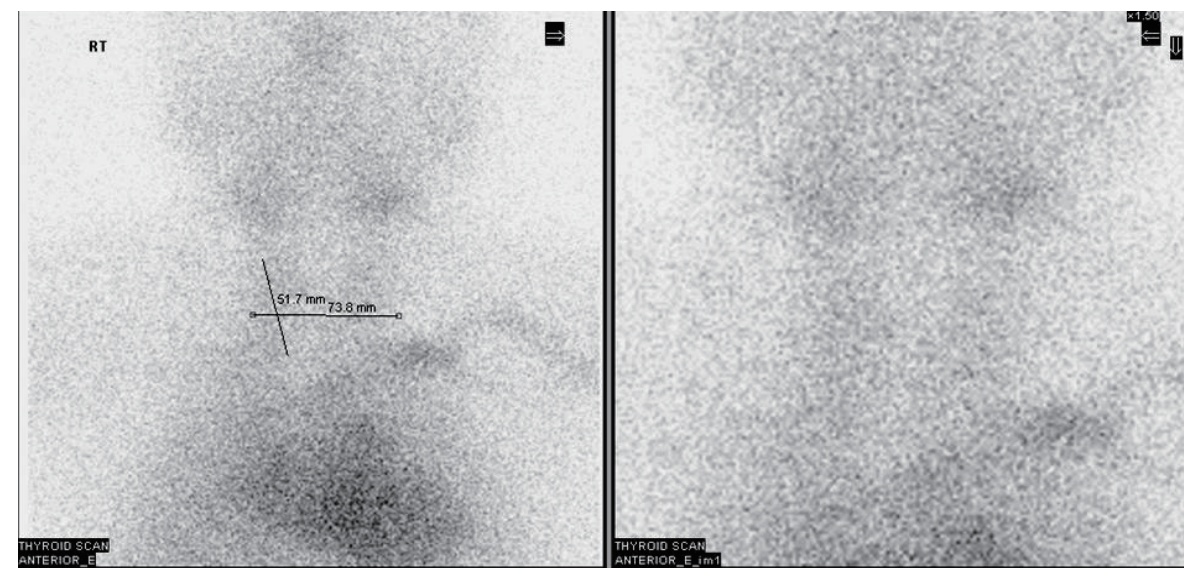

Fig. 2. Thyroid scintigraphy with ${ }^{99 m} \mathrm{Tc}$ shows a substantial decrease in uptake in both lobes.

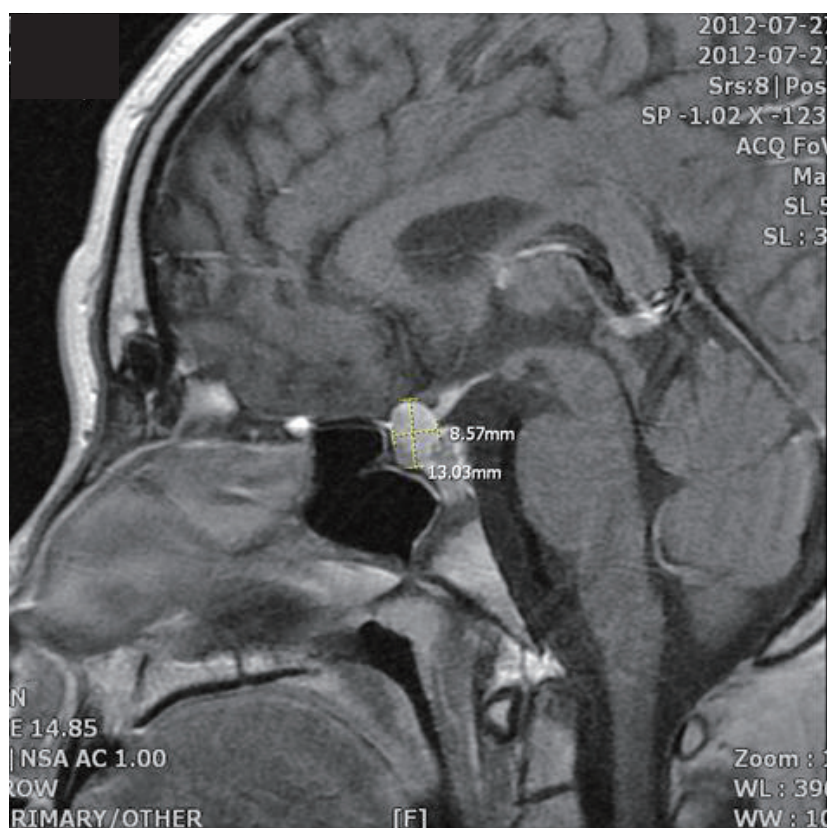

Fig. 3. Magnetic resonance imaging demonstrates an enlarged pituitary gland, with upward convexity, $13.0 \mathrm{~mm}$ in height and $8 \mathrm{~mm}$ at the transverse diameter.

After 1 year, the patient's height was $166.2 \mathrm{~cm}(50-75 \mathrm{th}$ percentile), which is an $11 \mathrm{~cm}$ gain in height and his weight was $66 \mathrm{~kg}$ (75-90th percentile). His BMI also improved to $23.9 \mathrm{~kg} / \mathrm{m}^{2}$ (75-85th percentile). Bone age was 14.5 years with the chronological age of 14 years. He was performing well academically.

\section{Discussion}

The neurologic manifestations of hypothyroidism are protean, affecting both the central and peripheral nervous system. The most common form of mononeuropathy is carpal tunnel syndrome, that results from compression by myxedema tissue in and around the median nerve, and leads to increased compartmental pressure within the carpal tunnel. Symptoms such as pain, paresthesia, or weakness of the wrist are typically found in the hand and forearm.

The anatomical course and confinement of the facial nerve are similar to the confinement of the median nerve in the wrist. Both nerves may be vulnerable to the profound metabolic and soft tissue changes of hypothyiroidism. Thus, peripheral facial palsy with hypothyroidism may be a nerve entrapment syndrome like carpal tunnel syndrome ${ }^{2,3)}$.

Bell palsy is an acute unilateral idiopathic paralysis of the facial nerve. The pathophysiology is unknown, but the autoimmune system was proposed to be involved by causing local damage to myelin after activation by a viral infection ${ }^{1)}$.

In this report, our patient had no history of a viral infection, and did not respond completely to treatment by prednisolone and antivrial medication as was expected. After medication were replaced with thyroxine, his symptoms recovered completely. Therefore, the facial palsy of our patient may not have been due to Bell palsy, but rather due to an entrapment neuropathy. Even if Bell palsy was the cause, the myxedema tissue may have been too compromised to allow for resolution.

Although our patient had severe hypothyroidism, he did not visit hospital earlier owing to the absence of goiter. The most common cause of acquired hypothyroidism in children and adolescents is chronic autoimmune (Hashimoto's) thyroiditis. In the chronic autoimmune thyroiditis, the most common physical finding at presentation is a goiter. However, some patients have no goiter or even have an atrophic thyroid gland. These are considered manifestations of the same disease with differing clinical phenotypes. By Carle et al. ${ }^{4)}$ the thyroid volume in autoimmune thyroiditis follows a normal distribution. Cases with thyroid atrophy and goiter are only extremes within this distribution.

In patients with hypothyroidism, the finding of a high serum antithyroidal antibody concentration is sufficient to diagnose chronic autoimmune thyroiditis. Antithyroglobulin antibodies and antithyroid peroxidase antibodies are used as markers of thyroid autoimmunity, but do not have any significant functional importance. 
TSH receptor antibodies (TRAbs) block TSH from binding to thyroid cells, which was measured as the level of TSH binding inhibitory immunoglobulins (TBII) using immunoassay. TBIIs do not distinguish agonistic from antagonistic autoantibodies. TRAbs have been classified as: thyroid stimulating antibodies (TSAb), TSH-stimulation blocking antibodies (TSBAb). These antibodies can mimic or block TSH induced stimulation of thyroid growth and hormonogenesis ${ }^{5}$.

TSAb stimulate the thyroid gland and cause Graves' hyperthyroidism. However, TSBAb may contribute to the severity of the hypothyroidism by blocking TSH-stimulation of the thyroid gland ${ }^{(6-9)}$, and disappearance of TSBAb is associated with the resolution of hypothyroidism ${ }^{10)}$. If TSBAb is present in a substantially high concentration in the maternal circulation, transplacental transmission can cause transient neonatal hypothyroidism ${ }^{11}$. Both TSAb and TSBAb can be found in some patients with autoimmune thyroiditis. The balance of TSAb and TSBAb determines whether a patients has hypothyroidism or hyperthyroidism $^{12)}$.

In the studies in adults, TSBAb appeared to be more common in patients with atrophic autoimmune thyroiditis ${ }^{6-9)}$. However, TSBAb had been found also in patients with goitrous autoimmune thyroiditis. Although TSBAb positive goitrous thyroditis patients recovered from hypothyroidism, TSBAb positive atrophic thyroditis patients continued to have hypothyroidism $^{13)}$.

There are very few data published in children and adolescents. A previous study on children and adolescents with chronic autoimmune thyroiditis found TSBAbs in goitrous as well as nongoitrous autoimmune thyroiditis patients. TSBAbs were found in $9.2 \%$ of total unselected patients, and $17.8 \%$ of patients with more severe hypothyroidism (defined as TSH level $>20$ $\mathrm{mU} / \mathrm{L}$ ). In those with severe hypothyroidism, a low prevalence of goiter was observed. Therefore, it was concluded that TSBAbs substantially contribute to the severity of the hypothyroidism in some children with chronic autoimmune thyroiditis ${ }^{14}$.

We could not measure TSBAb levels, but the TRAbs (TBII, immunoassay) level was $>40 \mathrm{IU} / \mathrm{L}$, and bioassays results for TSAbs were negative. Therefore, we considered TRAbs to be TSBAb, that caused thyroid dysfunction in this patient.

\section{Conflict of interest}

No potential conflict of interest relevant to this article was reported.

\section{References}

1. Yilmaz U, Cubukçu D, Yilmaz TS, Akinci G, Ozcan M, Guzel O. Peripheral facial palsy in children. J Child Neurol 2013 Oct 4 [Epub]. http://dx.doi. org/10.1177/0883073813503990.

2. Earll JM, Kolb FO. Facial paralysis occurring with hypothyroidism: a report of two cases. Calif Med 1967; 106:56-8.

3. Cox NH, Chew D, Williams JG, Morris AI. Bell's palsy associated with hypothyroidism. Br J Clin Pract 1985;39:158-9.

4. Carle A, Pedersen IB, Knudsen N, Perrild H, Ovesen L, Jorgensen T, et al. Thyroid volume in hypothyroidism due to autoimmune disease follows a unimodal distribution: evidence against primary thyroid atrophy and autoimmune thyroiditis being distinct diseases. J Clin Endocrinol Metab 2009;94:833-9.

5. Smith BR, Sanders J, Furmaniak J. TSH receptor antibodies. Thyroid 2007; 17:923-38

6. Konishi J, Iida Y, Endo K, Misaki T, Nohara Y, Matsuura $\mathrm{N}$, et al. Inhibition of thyrotropin-induced adenosine 3'5'-monophosphate increase by immunoglobulins from patients with primary myxedema. J Clin Endocrinol Metab 1983;57:544-9.

7. Konishi J, Iida Y, Kasagi K, Misaki T, Nakashima T, Endo $\mathrm{K}$, et al. Primary myxedema with thyrotrophin-binding inhibitor immunoglobulins: clinical and laboratory findings in 15 patients. Ann Intern Med 1985;103:26-31.

8. Arikawa K, Ichikawa Y, Yoshida T, Shinozawa T, Homma M, Momotani N, et al. Blocking type antithyrotropin receptor antibody in patients with nongoitrous hypothyroidism: its incidence and characteristics of action. J Clin Endocrinol Metab 1985;60:953-9.

9. Chiovato L, Vitti P, Santini F, Lopez G, Mammoli C, Bassi $\mathrm{P}$, et al. Incidence of antibodies blocking thyrotropin effect in vitro in patients with euthyroid or hypothyroid autoimmune thyroiditis. J Clin Endocrinol Metab 1990;71:40-5.

10. Takasu N, Yamada T, Takasu M, Komiya I, Nagasawa Y, Asawa T, et al. Disappearance of thyrotropin-blocking antibodies and spontaneous recovery from hypothyroidism in autoimmune thyroiditis. N Engl J Med 1992;326:513-8.

11. Brown RS, Bellisario RL, Botero D, Fournier L, Abrams $\mathrm{CA}$, Cowger ML, et al. Incidence of transient congenital hypothyroidism due to maternal thyrotropin receptorblocking antibodies in over one million babies. J Clin Endocrinol Metab 1996;81:1147-51.

12. Takasu N, Yamashiro K, Ochi Y, Sato Y, Nagata A, Komiya I, et al. TSBAb (TSH-stimulation blocking antibody) and TSAb (thyroid stimulating antibody) in TSBAb-positive patients with hypothyroidism and Graves' patients with hyperthyroidism. Horm Metab Res 2001;33:232-7.

13. Takasu N, Matsushita M. Changes of TSH-Stimulation blocking antibody (TSBAb) and thyroid stimulating antibody (TSAb) over 10 years in 34 TSBAb-positive patients with hypothyroidism and in 98 TSAb-positive Graves' patients with hyperthyroidism: reevaluation of TSBAb and TSAb in TSH-receptor-antibody (TRAb)positive patients. J Thyroid Res 2012;2012:182176.

14. Feingold SB, Smith J, Houtz J, Popovsky E, Brown RS. Prevalence and functional significance of thyrotropin receptor blocking antibodies in children and adolescents with chronic lymphocytic thyroiditis. J Clin Endocrinol Metab 2009;94:4742-8. 